\title{
Pension rights of Valea Jiului mining companies' clerks through the privately administered pension house
}

\author{
Oana Dobre-Baron ${ }^{1 *}$ \\ ${ }^{1}$ University of Petroșani, Faculty of Sciences, Department of Economic Sciences, University Street \\ 20, Petroșani, Romania
}

\begin{abstract}
Since their founding at the end of the XIXth century, the mining companies that have extracted coal in the Jiu Valley have tried to guarantee, though a private system of social security, pension rights for all of its employees, workers as well as clerks. This private system of social security would perpetuate itself, in the case of clerks working for Valea Jiului mining companies, though the interwar years up to the instauration of the Communist regime, when another pension scheme was established for those employees in the workforce. In this study we will seek to uncover the way in which these mining companies' clerks' Pension Houses were constituted and functioned after the First World War. They would operate on the basis of their own rules/statutes, would be under the leadership of a Committee chosen among the members of the Pension House, but also under the supervision of the Administrative Council of the mining company. Due to the levies placed upon their members, subsidies given by the mining companies, and other income, the Pension Houses managed throughout the entire period in question to guarantee honorable pensions for their members, and also for their widows and descendants.
\end{abstract}

In order to provide the different types of employees' pensions, within the Valea Jiului Mining companies there would operate, up to the Interwar period, workers' Fraternal Houses Bruderlade - including those for cases of illness and accidents and the Clerks' pension Funds.

From 1919 the Funds of the old workers' Fraternal Houses were taken over in the Central Social Security House system [1, p. 285-286, 296-297], the Mining companies having the obligation to manage the clerks' Pension fund and to maintain a decent pension.

After the "Petroşani" Mining Company was built on the 1st of January 1921, it kept the old clerks' Pension House, received from the "Salgótarján" Company, but from the 1st of May 1923 a Statute of the Pension House, which was approved in the general assembly of the 19th of April 1923, would come into force, and, practically, the "Petroşani" Company clerks' Pension House would be created, which would also acquire, through a decision of the Administrative Council, the 22 clerks who belonged to the "Salgótarján" Company Pension House and continued their activity within the Jiu Valley.

\footnotetext{
*Corresponding author: OanaBaron@upet.ro
} 
According to art. 1 of the "Petroşani" Company clerks' Pension House Statute, the purpose of the Pension House was to guarantee for the permanent clerks a pension which, after their deaths, could be reversible over their widows and children. Within the House there were all the permanent clerks of the Company, regardless of sex and who were at least 21 years of age: senior and junior clerks from the Bucharest General Directorate, as well as from the Petroşani Mines Directorate and from the other mines of the Company. Junior clerks of the "Petroşani" Company who, distinguishing themselves in their service, would be appointed, at one point of their careers, permanent clerks, had the right of having their time participated in the House recognized, equal with half of the years served as junior ministers, pouring the dues given by Statute, for a number of years equal to the recognised one.

The Pension House's income came from: members' dues; the Company's contributions; fructifying the House's wealth; donations or wills. Each member of the Company pour: $5 \%$ monthly of their base salary; $20 \%$ of a month's base salary, when joining; $50 \%$ of basic salary rises for a month, upon promotions, while the Company contributed to the House's wealth with a sum equal to the dues borne by the members.

The right to a pension was born after ten years contribution to the House, with the following conditions: was fired without blame from Company service and was at least 50 for men and at least 45 for women, or upon becoming such; due to a lack of capacity to work which came about after contracting a disease during and due to work and could not be cured not even after a year; after 30 years of service or 60 years of age. The pension's amount was calculated based on the average base salary from the five years of work before retirement: $30 \%$ after ten years of service and an additional 3,5\% for each subsequent year in service; after 30 years of service the pension was equal to the average base salary of the last five years of work, the maximum monthly pension being 2.000 lei. The pension such determined was an irrevocable, but not irreducible, right, so that all pensions, including the maximum, were reviewed yearly, growing or shrinking based on living conditions. Furthermore, the total given pensions could not exceed the available funds and, consequently, in the case of insufficient funds, all pensions were reduced proportionally, in order that the capitalised funds not be attacked.

They lost the right to a pension those who were removed for service due to ill-will towards the Company and those who were condemned for infractions detailed in art. 24 of the General State pensions law. The Administrative Council could put up for withdrawal, in order to adjust their right to a pension, anyone of at least 50 years of age for men and 45 for women, or even below, if they were not capable of fulfilling their work obligations.

Through art. 19-30 of the Statutes the conditions in which widows and legitimate children of the deceased pensioners could receive the pension as well.

Administering the Pension House, as well as liquidating the right to a pension was done by a Committee under the supervision of the "Petroșani" Company Administrative Council, composed of: the president of the Administrative Council, as president; the general director of the Company, as vicepresident; five members, two of which appointed by the Administrative Council and three chosen amongst the Mines' clerks by the active members for a period of three years.

The House's wealth was the property of its members and was administered separately within the "Petroșani" Company and kept by the Bucharest General Directorate. The pension fund received as bonus interest equal with the discount of the Romanian National Bank.

The dues to the Pension fund, from the 1st of March 1921 to the 1st of April 1923 were to be paid by the House's members in eight monthly installments, beginning with the 1 st of May 1923 [7, p. 1-14].

On the 24th of March 1924 the first yearly meeting of the Pension House Committee of "Petroşani" Company's clerks took place, during which from the Jiu Valley the following were elected: eng. Tiberiu Timoc, eng. Ştefan Lugosi, Iosif Schreiner. 
According to the 31st of December 1923 balance sheet, the Pension House had 77 active members and a total income of 4.930.489,63 lei from the dues poured in 1923 in accordance with art. 4 and 5 of the Statutes: $5 \%$ dues, $20 \%$ enrollment tax, $50 \%$ dues from the promotion base salary bonus; from the "Petroșani" Company dues, in accordance with art. 6 of the Statutes, the sum being equal to the sum gathered from dues and enrollments; from the sum of 4.1 million lei with which the "Petroșani" Company benevolently contributed, to the growth of the Fund, an operation that the Company would repeat in the following years as well, with different sums; from interest. There not being any expenses, the full sum was reported for 1924 [4, dos. 1/1921-1927, f. 24-25].

According to the 1924 balance sheet, the Pension House had 87 active members and a capital of 6.611.715,40 lei, the "Petroşani" contributing this year as well, with: administering the House's funds; a sum equal to the deposits of the House's members; the bonus interest of the House's income; a sum of one million lei donated for the clerks who were former members of the "Salgótarján" Company Pension House and recognised as members of the "Petroşani" Company Pension House [4, dos. 1/1921-1927, f. 26].

On the 31st of December 1925 the Pension House had 95 active members and a wealth of 7.456.716,24 lei, out of which 4.511.930 lei were placed into the Romanian Bank, 507.285,24 lei to the "Petroşani" Company, and with 2.437.500 lei the first installment was covered, as well as the issuance charges of the 7500 subscribed charges, with the aim of making the capital more rentable, to the National Industrial Credit Company capital [4, dos. 1/1921-1927, f. 27-28]. The House's income would grow constantly, so that on the 31st of December 1929 the House's funds rose to 29.776 .055 lei [4, dos. 2/1935, f. 175-176; 184186].

At the creation of the "Lupeni" Company in 1925 even though there were 26 clerks employed by the Bucharest General Directorate and 106 clerks by the Lupeni Mines Directorate, a clerks' Pension House would not be immediately created, such a House only being constituted on the 27th of June 1927, when the first meeting of the Management Committee took place.

It is true that, based on the decision of the general assembly of "Lupeni" Company shareholders of the 30th of April 1927, a decision invoked in art. 1 of the "Lupeni" Company Pension House Statutes, "there will be founded beginning with the 1st of January 1925 a Pension House having the aim of guaranteeing, in accordance with the current Statutes, a pension for the Company's personnel, respectively to their widows and children".

According to art. 2 of the Statutes, all employees considered to be clerks were ex officio and mandatory members of the House, as well as all duty personnel, if at the moment of employment they were 18 years of age but did not exceed 40 for men and 35 for women, had a permanent title and received a monthly retribution subject to withholding for pouring into the House. As for exceptions, these were not members of the House: directors and contractually employed personnel; mandatory members of similar State institutions, like the Circular House; new employees over 35 for women and over 40 for men, but who could enroll on demand with the basis of approval from the House Committee approved by the Company Administrative Council. Furthermore, the House Committee could recognised the years served with a provisional title, the clerk paying in this case the due withheld funds, with an interest equal to the discount of the Romanian National Bank, but no more than $5 \%$, the Company paying its share. They lost their right to a pension those who were fired because of their own fault and/or those who were condemned for infractions detailed in art. 67 of the General State clerks pensions law.

The right to a pension was born after paying dues for a minimum of 15 years, this right being kept even if the clerk, after 15 years of service, left the Company willingly or through being fired without blame. Liquidating the pension could be requested by a member of the House, if they had 30 years of service or at least 55 years of age, respectively 50 years for 
mothers or married female clerks. In case of death of a House member, the widow and legitimate successors had the right to a pension, respectively to aid in education, in accordance with the Statutes' provisions.

The House's income came from: members' dues; the Company's contribution, equal to the monthly dues of its members; donations, wills or other remittances; fines imposed on the House's members during service. Members' dues, which stopped after 35 years of participation as a member of the House, were: $6 \%$ of the monthly base salary plus the costliness bonus; $20 \%$ of the base salary and costliness bonus for a month upon joining; the monthly bonus for promotion.

For the calculation of the pension the base was the last sum, composed of the base salary and the costliness bonus, to which there were withholdings in the month preceding the retirement.

The monthly pension would represent, after 15 years of participating in the Pension House, $30 \%$ of the sum which would be taken as a basis and would grow in the next 20 years with $2,5 \%$ yearly, up to 35 years of participation, the pension reaching $80 \%$. For each modification of the salary, the Administrative Council would increase or reduce the pensions proportionally with the growth or decrease of salaries.

The Statutes established in art. 27-43 the right of descendants to a pension and aid in education, aid to the injured and ill.

The Pension House was represented in front of the authorities by the "Lupeni" Company, while administering the House, besides the cases reserved through the Statues to the Administrative Council, was done by a Committee composed of: the president of the Administrative Council or a vicepresident, as president; the general director of the Company, as vicepresident; five members of the House, two appointed by the General Directorate and three by the active members of the House, for a five year term. Out of the five members, two would come from the General Directorate and three would be elected by the Mines, participation being honorific [4, dos. 3/1925, f. 1-15].

Guaranteeing the right to a pension of the clerks was done until June 1927 by a Committee created at the General Directorate of the Company, and after that by a Management committee created in accordance with the statutes.

During the first meeting of the Management committee on the 27th-28th of June 1927 the problem of covering the differences between the sums withheld as advances for the dues and the statuary dues was discussed, the decision being that the sums would be withheld by the "Lupeni" Company from the House members' salaries; the same thing would be done for the dues owed between the 1st of January 1925 and the 1st of July 1927. Furthermore, it was agreed with the "Urikany" Company that the time served by clerks within the "Uricani-Valea Jiului" Company who remained after the 1st of January 1925 within the "Lupeni" Company would be recognised, the Hungarian Company accepting to pay the "Lupeni" Company 5 million lei for this recognition, payable in five yearly installments, ot he Pension House could give an $8 \%$ discount on all installments of the "Urikany" Company, receiving on the date when the convention was signed 4.2 million lei, this last option being taken into account [4, dos. 2/1935, f. 264-270].

As for the material condition of the House, it was ascertained on the 1st of January 1927 that the "Lupeni" Company Pension House funds were 5.3 million lei, and on the 31st of December 1927 the Pension House funds were 13.105.386 lei, a sum which came from: Pension House members' dues; the equal contribution of the "Lupeni" Company; interest; donations taken from the former "Uricani-Valea Jiului" Company and from the "Lupeni" Company; fines. From this sum it was paid in pensions 101.874 lei and 19.504 lei in administrative expenses. The net Fund of 12.983,882 lei would be given for safe-keeping and fructification to the "Lupeni" Company. 
In the following years the funds kept a high value, so that, on the 31 st of December 1928 the House had 16.496.379 lei, 18.566.100 lei on the 1st of January 1930 and 22.292.858 lei on the 31 st of December 1930, a wealth with which this House would come with within the "Petroşani" Company Pension House after the fusion of the "Petroşani" and "Lupeni" Companies on the 29th of May 1931 [3, dos. 74/1927-1930, f.f.; 4, dos. 2/1935, f. 201, 235240].

Unifying the Pension Houses of the clerks who worked besides the two Mining Companies would happen on the 1st of June 1931, as per the decisions of the general assembliess of the "Petroşani" and "Lupeni" Companies on the 29th of May 1931, practically a new clerks' "Petroşani" Company Pension House being formed, which would operate on the basis of the new Statutes. The new Pension House would overtake the funds and members of the Pension Houses adjacent to the two Mining Companies, the seniority rights of the overtaken members being recognised. The new Pension House would be dedicated only to the senior clerks of the "Petroşani" Company, the junior clerks having to be fitted within the general social security system of the State, with the exception of those who were already members of the two Pension Houses which were being unified.

All employees of the "Petroşani" Company considered to be clerks were considered to be ex officio and mandatory members of the House - with the exception of those detailed in art. 4: directors and contractually employed personnel; junior clerks, so called in accordance with the classification approved by the Administrative Council, and duty personnel, with the exception of those who gained their rights through the Statutes of the old "Lupeni" and "Petroşani" Pension Houses; the members of similar State institutions, like the Circular House, required by the law; new employees over 40 for men and over 35 for men - if at the moment of employment they were 21 for men and 18 for women and did not exceed 40 for men and 35 for women, they had a permanent title and received a monthly retribution susceptible to withholdings poured into the House. Provisional clerks became members of the House once they were given a definitive title, providing they were at least 21 .

The right to a pension was born after paying dues for at least 15 years, this right being kept even if the clerk left the Company voluntarily due to a disability or illness, or was fired without blame.

Liquidating the pension could not be requested by a member of the House before 30 years of service or 55 years of age for men/50 for mothers or married female clerks, with the exception of those who could not work due to illness or a disability, for which the pension would be liquidated immediately. The General Directorate of the Company, with the approval of the Administrative Council for directors and senior personnel, could always put its employees up for withdrawal from their office in order to adjust their eventual rights to a pension. In the case of death of a House member after the 15 years contribution, their widow or legitimate successors had the right to a pension, respectively to educational aid, as per the Statutes. The right to a pension was lost in the case of being fired due to their own fault and/or for being condemned for infractions contained within art. 67 of the General State clerks pensions law, even if they were done after retirement.

The income of the Pension House came from: members' dues; the Company's dues equal to the sum of the members' dues, including those for enrollment and promotions; donations, wills or other remissions; the income of the House's wealth; fines imposed upon the House's members. The dues paid by the House's members were $6 \%$ of the monthly base salary, plus the costliness bonus; $50 \%$ of the base monthly salary, plus the costliness bonus for a month on enrollment; the monthly base salary bonus obtained in six months of membership upon promotion, plus the costliness bonus. The payment of dues stopped after 35 years participation as a member of the House.

For calculating the pension the last sum was taken as a basis, namely the base pay, plus the costliness bonus, to which withholdings were made in the month preceding the retirement. 
The monthly pension would represent, for the 15 years contribution, $30 \%$ of the base sum, which will increase for the next 20 years by $2,5 \%$ yearly, up to 35 years contribution to $80 \%$, a rate which could not be surpassed just like the maximum pension could not exceed 400.000 lei per year, valued relative to the 1 st of June 1931. At each modification of the salary the Administrative Council of the "Petroşani" Company would increase or decrease the pensions proportionally with the growth or shrinking of salaries.

The only people who had the right to a pension after a deceased member with 15 years contribution were the widow and children, while the divorced wife had the right to food. Legitimate(d) children of a member of the House that had the right to a pension upon their death had the right to a subsidy for education. Global aid could be given to ascendants who lacked the means to live and who were supported by a deceased person, while to a House member on vacation or available without salary could be given aid for their sickness equal with the last pay, plus the costliness bonus, for a maximum of three months.

The clerks' Pension House was represented in front of the authorities and justice by the "Petroşani" Company, which also had the right to control and to veto conclusions that went against its interests. Administering the Pension House, besides the cases reserved through the Statutes to the Administrative Council, was done by a Committee comprised of: the president of the Administrative Council or one of its vicepresidents, as president; the general director as vicepresident; seven members of the House inactive service, three from the General Directorate and four from the Mines, among which three were appointed by the General Directorate, and four were appointed by the members of the House [8, p. 1-16].

During the general assembly of the shareholders on the 23rd of June 1933 it would be decided to modify art. 55 of the Statutes, which said that members of the Pension House having at least 15 years contribution, who have left their job against their will before fulfilling the conditions, would be able to request up to the 31st of December 1933 the establishment of their right to a pension. The pensions would be calculated according to $\S 19$ of the Statutes and would be paid beginning with the giving of salaries by the Company, with the exemptions from $\S 8$, let. B. of the Statutes. Furthermore, those who left employment against their will and did not have at least 10 years contribution could ask to have their right to a pension established up to the 31 st of December 1933. The pension would represent $30 \%$ of their base salary, plus the costliness bonus from the Company [5, dos. 2/1931, f. 10-11].

On the 29th of October 1931 a meeting took place for the creation of the first Committee after the fusion, with a five year mandate [4, dos. 2/1935, f. 113].

Within the meeting it was ascertained that unifying the two Pension Houses would come into effect on the 1st of June 1931, while from the accounting documents 64.008.836 lei was their combined wealth, out of which 43.276.182 lei was from the "Petroşani" Company and 21.732.654 lei from the "Lupeni" Company [4, dos. 2/1935, f. 114].

The wealth would grow to 70.123 .800 lei on the 31 st of December 1931, out of which 68.266.776 lei were deposited for fructification to the "Petroşani" Company, while 1.857.024 lei were invested in: 29.962 shares of 1 leu/share to the Jiu Valley Workers' Consumption; Iaşi Municipal Bonds 5\%, worth 664.562 lei; 646 a piece Land Reform Rent 1922 5\%, worth 1.162.500 lei [4, dos. $2 / 1935$, f. 88]. 
Table 1. Balance sheet and Profit and loss account of the Pension and Aid House of the "Petroşani" Company Clerks at the 31st of December 1932 [6, dos. 17/1932, f. 78-79]

\begin{tabular}{|c|c|c|c|c|c|}
\hline \multicolumn{3}{|c|}{ Balance sheet } & \multicolumn{3}{|c|}{ Profit and loss account } \\
\hline \multirow{2}{*}{ - } & Active & Passive & \multirow{2}{*}{-} & Debit & Credit \\
\hline & \multicolumn{2}{|c|}{ lei } & & \multicolumn{2}{|c|}{ lei } \\
\hline Clerks' contributions & - & 1.495 .214 & Clerks' dues & - & 17.920 .138 \\
\hline Company's contributions & - & 2.315 .313 & \multirow{2}{*}{$\begin{array}{c}\text { Company's contributions, } \\
\text { regular } \\
\text { special }\end{array}$} & \multirow{2}{*}{ - } & \multirow{2}{*}{$\begin{array}{l}16.977 .419 \\
17.402 .063\end{array}$} \\
\hline Interest & - & 7.351 .157 & & & \\
\hline Donations & - & 1.050 .000 & \begin{tabular}{|l|} 
The "Salgo- \\
Urikány" contribution
\end{tabular} & - & 5.477 .473 \\
\hline Special income & - & 228.561 & Interest & - & 28.574 .441 \\
\hline Retirements & 3.971 .473 & - & Special income & - & 2.553 .232 \\
\hline Total & 3.971 .473 & 12.440 .245 & Total & - & 88.904 .766 \\
\hline 1932 surplus & 8.468 .772 & - & Paid pensions & 9.965 .417 & - \\
\hline Total & 12.440 .245 & 12.440 .245 & Taxes and charges & 346.777 & - \\
\hline & & & Total & 10.312 .194 & - \\
\hline & & & $\begin{array}{l}\text { Remaining on } 31 \text { Dec. } \\
1932\end{array}$ & - & 78.592 .572 \\
\hline
\end{tabular}

The 1932 surplus, worth 8.468.772 lei, was added to the capital worth 70.123 .800 lei, which existed at the beginning of this year, while from the sum of 78.592.572 lei, 77.262.130 lei were placed to be fructified in the "Petroşani" Company, and 1.330 .442 lei were municipal bonds and land securities.

In the following years, as would happen during the entire period that we are analysing, a constant growth of the House's wealth could be seen and the guaranteeing of the same level of pensions for those who left active service, but also for the descendants of House members or pensioners who would die in the following years. On the 1st of January 1936, there were 245 active members of the House and there were paid until the 31 st of December 77 pensions for pensioners and descendants [4, dos. 4/1937, f. 73-82].

On the 31 st of December 1939 the House's wealth was 142.502 .088 lei, out of which: land worth 2.048.874 lei in Eforie and Predeal; bills of exchange and shares, worth 22.289.625 lei, in Iaşi Municipal Bonds and Land Reform Rent 1922; 40.172 "Credit for Electric Companies" shares; 118.163 .589 lei for fructification to the "Petroşani" Company [4, dos. 4/1937, f. 22-23].

And in 1940 there was a surplus of 10.785 .977 lei, the House's wealth growing to 153.790.275 lei, money which would be placed identically to 1939 [4, dos. 3/1940, f. 2-3].

On the 27th of February 1935 there would be discussions within the "Petroşani" Company Administrative Council about the consequences of the Social security law of the 8th of May 1933, which put junior clerks in the service of the "Petroşani" Company, from the point of view of the disability pension, in the same category with the workers, being able to receive a maximum monthly pension of 1.200 lei, which was thought to be too small. 
It was decided to create a Pension Fund for junior, technical and administrative clerks, with an equal contribution from the people and the "Petroşani" Company, in accordance with the Statutes of the senior clerks' Pension House.

The Statutes of the new junior clerks' Pension Funds were to be approved by the general assembly of the shareholders [5, dos. 2/1935, f. 2-3] and within the general assembly of the "Petroşani" Company on the 28th of March 1935 it was decided to create this Fund [5, dos. 1/1934, f. 9].

According to the Statutes, from the 1st of January 1935, the Pension Fund of the junior clerks of the "Petroşani" Company was created, which would pay old age and disability pensions to junior clerks and their families.

Junior clerks became ex officio and mandatory members of the Fund, from the day of their naming with a definitive title in the service of the "Petroşani" Company. They were officio and mandatory members of the Fund, regardless of age or sex all of the Company's employees which were junior clerks on the 1st of January 1935, with the exception of those who at that date were members of the "Petroşani" Company senior clerks' Pension House. The junior clerks of Companies affiliated with or under the control of the "Petroşani" Company could also be members of this Fund, if approved by the Administrative Council, under the condition that those companies contribute for their employees in the exact same manner as the "Petroşani" Company with regards to the pourings in this Fund. The junior clerks who entered and were definitively fitted into the service of the "Petroşani" Company after the 1st of January 1935 could not become members of this Fund if they were over 40 for men and over 35 for women. Junior clerks who were members of the Fund could redeem, with approval from the Administrative Council of the "Petroşani" Company, up to a maximum of ten years service seniority effectively rendered before the 1st of January 1935 for the "Petroşani" Company or affiliated or controlled companies.

The right to a pension was born after 15 years contribution to the junior clerks' Pension Fund, payment of the pension being able to be requested if the requesting person had 30 years of service and 55 years of age for men, respectively 50 for women; these conditions were not necessary for a member of the Fund, clerk of the Society or out of work, who could not work due to ill health or a disability. The right to a pension was lost by those fired due to their own fault or condemned for infractions detailed in art. 67 of the General State clerks pensions law.

The income of the junior clerks' Pension Fund came from: members' dues, which were not taken after 35 years as member of the Pension Fund; the contribution of the "Petroşani" Company equal to the members' dues; donations, wills and other remissions; the income of the Pension Fund's wealth; fines imposed upon the Fund's members during service.

Members' dues were: $6 \%$ of the monthly base salary plus the costliness bonus; $50 \%$ of the base salary plus costliness bonus for a month, on enrollment; the bonus for three months upon promotion to the base salary and the costliness bonus.

On calculating the pension the last sum - base salary and costliness bonus - was taken as a basis, to which withholdings were made in the month preceding the retirement. The monthly pension would be, after 15 years contribution, $30 \%$ of the base sum, and it would grow up to 35 years contribution by $2,5 \%$ for each year, going up to $80 \%$, a rate that could not be surpassed.

On the date a junior clerks' Pension FUnd member retired according to the current Statutes, the "Petroşani" Company would retain and pour to the Social Security House, from the monthly pension due to the respective member, the due contribution to the Social Security House so that being insured at this institution would not be interrupted up to the date the insured person would also be retired by this institution. The person who retired had the obligation to make all of the diligences necessary to obtain an old age pension or accident annuity from the Social Security House, the pension that they were going to receive later increasing with the pension received from the Social Security House, but without the two 
cumulated pensions exceeding the base salary plus the costliness bonus on the day of retirement from the Pension Fund. According to the Statutes, the only people who had the right to a pension after the death of the Pension Fund member with 15 years contribution or retirement were the widow and legitimate children.

The junior clerks' Pension Fund was represented in front of the authorities and justice by the "Petroşani" Company, which reserved the right to control and veto the decisions of the Fond's Committee. Administering the Fund, besides the cases reserved to the Administrative Council, was done by a Committee composed of: the general director of the "Petroşani" Company, as president, and one of their delegates, as vicepresident; five members of the Pension Fund in active service and coming from mining, two of which appointed by the General Directorate and three by the Fund's members, for a period of five years; activity in the Committee was honorific [9, p. 1-11].

On the 31 st of December 1937, the House had 540 members and a capital of 20.658.251 lei, which came from the 1937 surplus of 7.911 .072 lei, received from dues, the "Petroşani" Company's contribution and interest, to which it was added the capital existing on the 1st of January 1937, totaling 13.119.832 lei [6, dos. 7/1937, f. 107].

The next step in the "Petroşani" Company senior clerks' Pension House's existence took place from the 1st of January 1943.

Taking into account the fact that in 1935 a Pension Fund for junior clerks was created alongside the senior clerks' Pension House, and to respond to the demands of Decree-Law nr. 3736/7th of November 1940 regarding the modification of art. 310 and 313 of the Social security law of the 22nd of December 1938 [2], during the special general assembly of the "Petroşani" Company on the 30th of June 1941 it was decided to unify from the 1st of January 1943 the two Pension Funds and create a single "Pension and Aid House of the 'Petroşani' Company Clerks", a mandate being given to the Administrative Council to decide upon the form of the convention through which in the future the rights of clerks and their descendants to a pension, education and aid subsidies. [5, dos. 1/1940, f. 9].

The new House would be created and managed through a Founding Act written in accordance with the decision of the special general meting of the 30th of June 1941. Through this Founding Act the "Petroşani" Company recognised that the entire wealth of the two Pension Funds which functioned up until that point besides the "Petroşani" Company now belonged to the Pension and Aid House of the 'Petroşani' Company Clerks, created through this Act, and remittance in complete property would be accepted, a wealth of its own, distinct from this House being created.

The "Petroşani" Company would also be required to pour into the newly created House's account all of the dues that came from the withholdings done upon the clerks' salaries, enrollment taxes, promotion bonuses, as well as the share with which the "Petroşani" Company contributed.

Furthermore, the "Petroşani" Company was required to pour into the new House all of the income generated from placing and fructifying the wealth of the two old Pension Funds, to further grow the House's wealth through donations and with the yearly sums collected from the Company's beneficiaries, which were made available to the general assembly $[4$, dos. 6/1941, f. 1-2].

According to the balance sheet of the 31st of December 1941, the new House would possess a wealth of 198.067.802 lei, comprised of: $a$. goods of the former senior clerks' Pension House worth 153.790.275 lei: land - 2.061.467 lei; bills of exchange and shares 22.062.108 lei; cash - 129.666.700 lei; $b$. goods of the former junior clerks' Pension Funds, worth 44.277.527 lei [5, dos. 10/1942, f. 5].

On the 14th of April 1943 a meeting of the "Petroşani" Company clerks' Pension House Committee would take place, which would agree to the decision taken by the special general assembly of the 30th of June 1941 regarding the unification under the name of the "Pension 
House of the 'Petroşani' Company Clerks", of the two Houses that functioned up until that point, and the fusion would take place on the 1st of January 1943.

From this date, all obligations and rights to a pension and restitutions were to be done through the Statutes of the Pension House of the "Petroşani" Company clerks, and also the accountings and balance sheets of the two Funds would be unified, on the basis of the balance sheets made on the 31st of December 1942 [6, dos. 24/1941, f. 379-380].

Also on the 14th of April 1943 a meeting of the "Petroşani" Company junior clerks' Pension Fund Committee took place, which approved the fusion, so that on the 1st of January 1943 all obligations regarding dues, rights to a pension and restitutions to be done through the Statutes of the Pension House of the "Petroşani" Company clerks [6, dos. 24/1941, f. 427 428].

Obviously in accordance with the Statues, the Pension and Aid House of the "Petroşani" Company clerks would be headed by a Committee comprised of: president; vicepresident; seven members: four chosen amongst the Mining and General Directorate clerks and three appointed by the General Directorate [6, dos. 24/1941, f. 340].

Due to a good administration of the Fund, the size of the dues and the cash contribution of the "Petroşani" Company, the creation of an Aid Fund from which House members could borrow, interest to the deposited sums, and due to the fructification of a part of this wealth, the trend would be a positive one with regards to the soundness of the House, something which would allow in the following years a guarantee of the established value of the pensions, for the pensioners as well as for the widows and minor children.

Therefore, on the 31 st of December 1943, the House's wealth was 499.527 .875 lei, a sum which came from: 338.506.944 lei own capital; 15.045.875 lei aid Fund; 145.975.056 lei 1943 surplus [6, dos. 24/1941, f. 342].

On the 31 st of December 1944 the House's wealth was 554.084.271 lei [6, dos. 24/1941, f. 180], on the 31 st of December 1945 of 581.882 .316 lei [6, dos. 41/1945, f. 186], and on the 31 st of December 1946 of 1.370.275.638 lei, a sum which, due to rising inflation, came mainly from the own capital of 648.956 .847 lei and 661.524 .064 lei 1946 surplus [6, dos. 45/1945, f. 175].

Table 2. Balance sheet and Profit and loss account of the Pension and Aid House of the "Petroşani" Company Clerks at the 31st of December 1947 (lei) [6, 59/1947, f. 176]

\begin{tabular}{|l|c|c|l|c|c|}
\hline \multicolumn{4}{|c|}{ Balance sheet } & \multicolumn{3}{c|}{ Profit and loss account } \\
\hline & Active & Passive & & Debit & Credit \\
\hline Land and real estate & 37.559 .624 & - & Pensions A & 3.471 .460 & - \\
\hline $\begin{array}{l}\text { Bills of exchange and } \\
\text { shares }\end{array}$ & 1.006 .386 & - & Pensions B & 714.452 & - \\
\hline Petroşani S.A.R. & 1.231 .663 & - & Pensions C & 26.553 & - \\
\hline $\begin{array}{l}\text { Difference from wealth } \\
\text { recalculation }\end{array}$ & 259.818 .108 & - & Aid and damages & 150 & - \\
\hline Capital & - & 297.624 .444 & Various expenses & 71.857 & - \\
\hline 1947 surplus & - & 1.984 .800 & 1947 surplus & 1.984 .800 & - \\
\hline Aid fund & - & 6.537 & Dues A & - & 2.248 .638 \\
\hline Total & 299.615 .781 & 299.615 .781 & Dues B & - & 80.568 \\
\hline
\end{tabular}




\begin{tabular}{|l|c|c|}
\hline Dues R & - & 2.065 \\
\hline Company contribution & - & 3.065 .161 \\
\hline Interest and coupons & - & 124.549 \\
\hline Various incomes & - & 22.457 \\
\hline Total & 6.269 .272 & 6.269 .272 \\
\hline
\end{tabular}

The House's stability can also be seen in the conditions that we are seeing, in accordance with the provisions of. 20 of the Statutes, in the growth of the pensions' amount after the active clerks' pay raises of: $40 \%$ from the 1st of April 1942; $40 \%$ from the 1st of January $1943 ; 15 \%$ from the 1 st of January $1944 ; 35 \%$ from the 1 st of September $1944 ; 50 \%$ from the 1st of April 1945 [6, dos. 24/1941, f. 111, 175, 200, 382, 395].

\section{References}

1. Direcţiunea Regională a Asigurărilor Sociale Deva, Bilant şi conturi de resultate pe anii bugetari 1918, 1919, 1920-1921 a Casei Cercuale pentru Asigurările Sociale din Deva (Tiparul Tipografiei Francisc Heim, Deva, 1922)

2. Monitorul Oficial, I, nr. 264/10 noiembrie 1940, 6387-6388; I, nr. 298/22 decembrie 1938, 61666167

3. Serviciul judeţean Hunedoara al Arhivelor Naţionale, Fond Mina Lupeni (1895-1953), dos. 74/1927-1930, f.f.

4. Serviciul judeţean Hunedoara al Arhivelor Naţionale, Fond Societatea „Petroşani”. Direcţiunea Minelor. Casa de Pensii (1915-1953)

5. Serviciul județean Hunedoara al Arhivelor Naţionale, Fond Societatea „Petroşani”. Direcţiunea Generală. Consiliul de Administratie (1921-1953)

6. Serviciul județean Hunedoara al Arhivelor Naţionale, Fond Societatea „Petroşani”. Direcţiunea Minelor. Serviciul Contabilitate (1915-1953)

7. Societatea „Petroşani”, Regulamentul Casei de Pensiuni a funcţionarilor Societăţii (București, 1923)

8. Societatea „Petroşani”, Statutele Casei de Pensiuni (Tiparul Românesc, Bucureşti, 1931)

9. $\mathrm{xxx}$, Statutele Fondului de pensiune al funcţionarilor inferiori de la Societatea „Petroșani" (Tipografia „Jiul Cultural”, Petroşani, 1935) 